\section{FUTURE OF THE MILK INDUSTRY*}

\author{
By PROF. H. D. KAY, O.B.E. \\ Director of the National Institute for Research \\ in Dairying
}

$\mathrm{T}$ HE future of the milk industry in Great Britain is the key to two matters of extraordinary national importance. Its future is, by and large, the future of national nutrition ; its future is, no less, the future of British farming. An expanding milk industry is our best guarantee of a steady improvement in the health and physique of the rising generation ; a declining milk industry would foreshadow the rapid re-entry of British farming into the Slough of Despond. The future of the industry is not a thing to be regarded as starting after the War. It is starting now, and developments taking place to-day and during the War are influencing and shaping it continually. In fact, the War is catalysing valuable changes in the industry which might otherwise have taken years to accomplish, though slowing up other desirable developments that some of us had hoped to see before now.

The milk industry includes what is, in terms of money value, nutritional significance and numbers engaged, the greatest of our agricultural enterprises, that of dairy farming (having at the present time a turnover of some $£ 100$ millions a year), together with one of our major home industries, that of milk processing and distribution (having a turnover of some $£ 150$ millions a year). Technically, administratively and educationally, this large industry must in the future be regarded as one unit. For present purposes I shall not consider the closely related industries of cheese, butter and ice-cream manufacture, or the large ancillary trades concerned with the preparation of cattle feeding-stuffs.

\section{Need for Planning}

Freedom from want entails forethought. Our cavedwelling ancestors, rugged individualists all of them, may have spent a happy summer and autumn under the greenwood tree and fairly full of food, but their winters must have been extremely thin and meagre before they began systematically to plan their food supplies ahead and to till the soil.

The major half of agriculture-and by agriculture I mean continuous agriculture and not the crop snatching that has terminated in certain parts of the world in complete loss of fertility, or even in loss of the soil itself by erosion-is forethought and planning, planning not for a year, but for several years ahead. The producing side of the milk industry, founded on the all-the-year-round consumption of agricultural products by livestock, is an activity where careful planning ahead is particularly important. The matings occurring this spring are laying the foundations not merely for next winter's milk production but also for our milk supply in 1945. The education that we are giving - or not giving - our potential dairy farmers to-day is securing efficiency or piling up trouble for the 1950's and 60's. Unless we are completely dead to all the lessons which peace ought to have taught us and which the War is daily and rather painfully underlining, we must all be agreed that one of the fixed points for any post-war milk industry is that it must be organized as a unit.

- Substance of a paper read before the Royal Society of Arts on May 20.

\section{Objectives of the Milk Industry}

A planned system must have an objective. The primary function of the milk industry is now, and will continue to be after the War, to produce and distribute effectively, to all human beings who need it, when and where, and in what quantities they need it, and in the highest possible quality, a key foodstuff that is essential in certain stages of human life and of major value at any stage. Its secondary function, requisite for the performance of the first, is to provide a reasonable living for those engaged in the industry. The acceptance of this view with its stress on the meeting of human nutritional needs as the primary object of the milk industry means a fundamental change in the habits of thought of some of us, and has many implications which I cannot pursue now. One assumption, however, I must make, that any future Government of Great Britain will take over the mantle which the present Government is, I think, the first effectively to wear, in insisting that the steady improvement of the health and physique of the people, particularly of the rising generation, and the promotion of British agriculture, are two of their main and closely interlocked duties. Milk is central in both of these.

We are in the fortunate position that we can now give to the industry a fairly close estimate of our future national needs. As a result of a large body of experiments and surveys extending over the past twenty-five years we now know sufficiently well what is the average quantity of milk per head of the population that is needed for adequate nutrition, that is, needed to raise the nutritional level of our people to that at which optimal physical growth and development and general health (so far as they depend on nutrition) may be attained. It is not less than 0.8 pint per head per day, probably not less than 1.0 pint. At present our average consumption is just over 0.4 pint per head per day. This figure is slightly greater than the amount in Great Britain in pre-war days, but slightly less than that consumed in the very poorest of American cities.

On a yearly gallonage basis, 0.8 pint per headtaking the lower of the figures just mentionedmeans 1,650 million gallons a year. Liquid consumption is evenly distributed over the whole year, so that about 140 million gallons per month, winter and summer alike, will be needed. This means a 75 per cent increase in present winter milk production, though only a 30 per cent increase in summer production, assuming practically no milk for manu facture.

Two objections will rise to everyone's mind. First, will not the population, even if it has the money to buy the milk, slip back after the War into the peacetime habit of a low milk demand, so that any increase in production will merely mean more to be manufactured ? The second question is, will not the postwar home dairy farming industry and the purchasing power of our population both be too severely hit by war impoverishment to hope to attain anything approaching this level of supply or demand ? My reply is that it would be most unwise to underestimate the speed of recovery both in general economic level and in agricultural developments of an adequately mechanized civilization like our own provided we win the War, and provided we manage to canalize, in a socially positive direction both the enormous industrial forces and the great psychological drive that will be liberated when peace is declared. 
Could any part of these requirements be met by the importation of dried or condensed milk? Undoubtedly, but in relatively small part. To provide a year's supply some 800,000 tons of dried milk would be needed. The Southern Dominions, working all out on milk drying, might provide one-twentieth of this amount. Even if dried milk in the necessary quantity, flavour and ease of reconstitution could be imported, a good deal of persuasion would, in my opinion, be needed before it could be used in the household on any impressive scale. In bread and confectionery making, in the institute, canteen or restaurant, dried milk could readily be used to the limits of any visible or likely supply.

\section{Increased Efficiency of Dairy Farming}

To meet the liquid milk demands I have just envisaged, most dairy farmers in these not very large islands will have to increase their efficiency and improve their management very considerably.

The yield of milk per cow per year offers a wide field for improvement. From the 520-550 gallons of the pre-war years (now down to about 460) it could be raised in a decade or so by the use of knowledge we already possess (perhaps most rapidly by taking every advantage of artificial insemination from first-class sires) to 700-750 gallons. That this is a reasonable estimate of what can be done is supported by the fact that the yield per cow in Denmark some ten years ago was officially stated to be 704 gallons per cow. Further, by control, much of which is now possible, of sterility and other bovine diseases, the average length of milking life of a cow, now less than four lactations, could be steadily raised to six, seven or even more. Instead of being a very rare creature, the 5,000-gallon cow (that is, an average of about 700 gallons for seven lactations) would be found in most herds. To enable this objective to be more rapidly reached, not only must existing knowledge be rigorously applied, but also research in the control of cattle diseases, and particularly the physiological and pathological study of bovine sterility, pressed forward with renewed energy when some of our more immediate war tasks are ended.

We shall have to control more carefully the type of bull to be used in dairy herds. Any future scheme for the use of better sires will undoubtedly receive the hearty support of the milk-producing industry It is of interest to remember that the Ministry scheme for licensing bulls, which was rather unwisely allowed to lapse at the outbreak of war, was put into action again at the urgent request of the farmers themselves. The use of any bull inferior to the son of a proved sire out of a high-yielding dam ought, in fact, to be increasingly discouraged in the future in any herd pretending to be a dairy herd. In addition, a simple system of milk recording, without which no dairy farmer can effectively plan his feeding, breeding or culling programme, will have to be made, if not universal, as near universal as makes no matter.

Present milk shortage is due as much to lack of knowledge as to lack of feeding stuffs. Next winter's milk production, as well as that in the post-war future to which I have been referring, depends largely on the more general practice of modernwhich are at the same time economical-methods of feeding. It is to be noted that per unit of feeding. stuff consumed, the 700-gallon cow is much more efficient than the 500 galloner.
After the War, if we are able to return to, and to pay for, the importation of suificient animal feeding-stuffs, the solution of the milk producer's winter feeding problem will be relatively easy. In any case we shall probably have to continue in part on the fundamentally sounder lines along which the War has driven us-the production of better quality protein-rich feeding-stuffs at home. Of these, the major ones for milk production are still good leafy grass during the growing season, which will, in the future, be extended on the average by a fortnight at each end, hay cut at a relatively early stage with as much clover in it as possible, and well-made silage from young grass or from an oats and pulse mixture. Young grass and grass products will probably continue for some years to be our main protein-containing foodstuffs for the dairy herd, and the basic knowledge that has been acquired in the last two decades as to how to improve productivity and stock-carrying capacity of grassland should enable us to meet increasing demands for the milkproduction ration without encroaching too severely on other types of farming or upsetting farming balance.

\section{Increase in Cow Population}

Even if we succeed in increasing the average yield per cow from the pre-war 520-550 up to $700-750$ gallons, it will only give us about 40 per cent of the increase in milk production that we require to meet human nutritional needs. In addition to increased individual yield, there will also have to be an increased dairy herd. From the present population of a little more than 3,200,000 cows and heifers in milk and in calf, it will have to increase to nearly $4 \frac{1}{2}$ millions.

As a result of improvements in grassland and grassland management, better knowledge of arable cropping for milk production, increasing soil fertility as the manurial output of the increasing herd steadily rises, and as artificial fertilizers are used with greater skill, this population should require little more dairyfarming acreage than does the present relatively inefficient herd.

The more the farm is self-supporting as regards cattle feeding-stuffs, the more is it necessary to put back into the soil those minerals inevitably lost in every gallon of milk leaving the farm. Concomitant with an increased milk output is, therefore, an increased requirement for lime, for basic slag and other phosphatic manures, for potash and for nitrogen.

\section{Larger Dairying Units}

Not only will there be in the future a larger population of dairy cows per 100 acres, but the average dairy-farming unit will also increase very considerably in acreage, with a decrease in the total number of holdings. The average dairy-farming unit at present is only some 12-14 cows strong, but the greater efficiency of a larger unit, where both general and specialist machines can be used to advantage, overheads spread over a larger acreage, cropping policy planned on a wider basis, disease control managed more effectively, purchases made on more economical terms, better arrangements made as regards hours of work, holiday periods and so on, needs no emphasis. It is repeatedly stated that dairy farming is a particularly onerous job. This is true while the units remain small. But with a larger unit, say one having not less than 40-50 cows in milk, where three or four men or more may be available for cow-shed work, a little organization 
should make it possible for the duties of feetung, milking and day-to-day operations generally to be scarcely more onerous than those on any other type of farm.

\section{Chartered Dairy Farmers}

An organized and planned milk industry may demand in the not too distant future standards of professional competence before would-be entrants into dairy farming are allowed to use land at all. It may also insist on the squeezing out into some other avocation in which he will do less harm, of the incorrigibly dirty and inefficient milk producer. Modern dairy farming demands, in no small measure, relatively new knowledge which should be a minimum asset of any who hopes to have the privilege of using a portion of our limited farming area to the best national advantage. The idea of the chartered dairy farmer is not so visionary as it sounds. Meanwhile, until vocational farming education on modern lines - which means, of course, no educational stunt, but the combination of new knowledge with ripe and tested experience in an organized course of training -can be extended to cover the needs of the large majority of new entrants into the farrning profession (instead of only about 10 per cent of them as at present) the appointment in all our dairying counties of competent dairy husbandry advisers is highly desirable.

\section{Improved Quality of Milk}

The future of milk quality has three aspects : that concerned with ordinary hygiene and cleanliness, that concerned with udder disease, and that concerned with compositional or nutritional quality. All these are closely linked up.

As regards cleanliness of production, absence of which leads, particularly in summer, to taints and souring, perhaps 50 per cent of farmers, mainly those who have been producing milk for some time and have learned the simple routine for avoiding con. tamination, tum out a oonsistently satisfactory article. As regards udder diseases, methods are now known for controlling the most important of these, streptococcal mastitis, and the national veterinary medical plan which is being put into practice on a voluntery basis should, if combined with an increase of the farmer's knowledge as to the simple methods he can himself use in the cow-shed to limit its spread, be of great assistance in diminishing the heavy toll of this disease on the quantity and the nutritional quality of our milk supply. As regards compositional quality of milk, practically no official attention has ever been given in Great Britain to the poor nutritional value of much of our market milk, to the great changes in its nutritive quality that may be brought about by changes in the nutrition of the cow, or as a result of chronic udder disease.

\section{Disease}

I have just mentioned one of the directions in which bovine disease affects the dairy farmer. Disease puts a gratuitous tax of at least 25 per cent on to the economic cost of every gallon of milk. Diseases, like tuberculosis and contagious abortion, which can cause human infection if the milk containing the organisms is consumed, are far less important from the consumer's point of view now that more milk is pasteurized, but are extremely important from the point of view of the dairy farmer, since they may easily ruin a first-class herd unless early reoognized and ohecked Some form of obligatory national veterinary health insurance seems likely in the fairly near future, together with an efficient State system of preventive veterinary medicine.

\section{Distribution}

Assuming that milk of satisfactory compositiont, hygienic and keeping quality has been produced by our future dairy farmer, let us consider the next steps. He will either deliver it hirnself to the buyer, or more usually have the churrs called for either at his farm or at some convenient place on the roadside, by the collecting lorry attached to the Iocal collecting depot or distributing dairy. In the future the churns will contain cooled milk, well below $65^{\circ} \mathrm{F}$. when they leave the farm, and will be placed, if they have to wait for a while, on a properly constructed platform with a light roof over it to protect the churns from direct summer sunshine. Transport rounds will be arranged so that such waiting is minimal. The lorries will leave clean and sterile churns on the platform, and take away the full churns to reach the collecting depot without delay. Here samples of milk will be systematically taken for the determination by quick, modern methods of compositional and keeping quality by a skilled tester working under a centrally organized and controlled milk quality scheme. On his findings fitting payment to the producer will be made. No milk, even that of poorest quality, will be returned to the producer. It will be appropriately salvaged. Slightly better milk which is of insufficient quality for the liquid milk market may be used for other purposes. The satisfactory milk will then either be brine-cooled or, better, pasteurized by the H.T.S.T. process before being sent forward immediately by rail, road, tank or churn to the distributing dairy.

In the very near future the waste of milk due to souring, which last summer reached a magnitude little short of scandalous, must be prevented. Methods for the prevention of souring, even in hot weather, have been thoroughly well worked out and are well known to many, perhaps half our dairy farmers, collecting-depots or creameries, and milk distributors. In the near future, every dairy farmer whose milk eonsistently fails to reach the necessary standard will be instructed on his farm by the county advisory staff on points of major importance, such as the adequate cleansing and sterilization of farm utensils, milking equipment and churns, and on methods for cooling the milk to below $65^{\circ} \mathrm{F}$. and keeping it cool. Hot weather provides in an almost literal sense an acid test of elficient milk production and handling, and the milk industry of the future will be ashamed of its technical inelficiency if souring or taint production continues to occur every time there is a hot spell.

Collecting depots and distributors in trouble will similarly be assisted by the provincial dairy bacteriologist. The producer is by no means always respon. sible if summer souring occurs. Faulty churn washing, too prolonged transport rounds, or some other factor not within his control may be to blame.

\section{Pasteurization Requirements}

The pasteurization bogey which has caused so much controversy and even ill-feeling in the past is now satisfactorily laid. Careful scientific experiment extending over some years has recently shown, and all those competent to assess the clear-cut ovidence 
now agree, that properly controlled commercial pasteurization causes practically no nutritional damage to milk. In the near future it will almost certainly be a national requirement that all milk sold for liquid consumption shall either be effectively pasteurized, or shall be from disease-free animals. The methods of pasteurization which will be used for the majority of town supplies after the War will undoubtedly be the H.T.S.T. process, recently officially accepted, which offers considerable technical advantages besides requiring far less space and metal than the old 'holder' process

A beneficial consequence of such a national requirement is that many of the dirtier milk-handling and distributing premises will have to shut down. This will save a good deal of the unnecessary and wasteful duplication of milk rounds that stil] persists even under present war-time conditions. It is quite absurd that in a town of 100,000 inhabitants there should be no fewer than 200 licensed distributors of milk, many of them working from domestic kitchens and back-yards under indescribable conditions. Ten distributing units, adequately staffed and hygienically equipped, could do the job far more satisfactorily. Whether compulsory pasteurization is introduced or not, careful re-inspection of all licensed milk distribution premises is urgently needed in the immediate future, with revocation of licence where ordinary conditions of decency are unattainable.

The milk-distributing, like the milk-producing side of the industry, suffers from having too many small, dirty and ineftcient units. It also suffers, even to a greater extent that the milk-producing side, from a paucity-almost a complete absence-of organized technical and vocational training and advisory help. Modern milk distribution is not a robot operation which can be carried out by unintelligent and untrained personnel. One of the pressing needs of the immediate future is the organization of courses of technical training in processing and distribution of milk

\section{Education and Research}

Any long-term view of the future of the milk industry must concern itself with $(a)$ the general education, and $(b)$ the vocational training of the dairy farmer, the milk distributor and manufacturer, and the housewife. The milk industry is founded on knowledge that is continually advancing and extending, and its future prosperity and ability to meet the demands which the nation will make on it will depend in large part on the rate with which new knowledge can be acquired, assimilated by the industry and effectively applied.

As regards the acquisition of new knowledge, the total number of workers dealing with the research problems of milk production, processing and distribution is very small, probably less than fifty for Great Britain. Compared with the magnitude of the industry, the extent to which it is based on scientific and technical knowledge, and the number and importance of the immediate problems, both fundamental and otherwise, that await solution, this number is almost incredibly small, able though the little handful may be, and until a year or so ago its financial resources were grossly inadequate.

One of the needs of the near future is increased facilities for semi-large-scale experiments, both on milk handling and processing problems, and in methods of milk production, with an adequate research staff to deal with them. (Research workers of the type $I$ have in mind require from five to ten years of post-graduate training before they can tackle such problems adequately, and the training of such workers is in itself a problem which the paucity of dairy research facilities in the past has rendered acute.) At present there are in several cases only two alternatives: either to leave a piece of work at the laboratory stage of development and trust that some better equipped country or some private firm will take it up, or to endeavour to go direct from the laboratory to the full industrial scale through the good will, and at the risk of, a firm in the industry. This latter method, even at the best, inevitably involves lack of control of details, of labour and of management that may make the difference between success and failure.

For experimental work on the improvement of milk production, research facilities are still meagre. Experiments on an adequate scale in dairy husbandry and on the physiology of the dairy cow will need, in the future, the use of several large experimental herds under careful control, if they are to have a prospect of success within a reasonable time.

As regards the dissemination and practical assimilation into agriculture without too great a time-lag of the results of research, the recently founded Agricultural Improvement Council should be, both in the immediate future and after the War, of considerable benefit to the production side of the milk industry, and to a smaller degree to the handling and distributive side. The maintenance of adequate financial. support for the activities of the Agricultural Research Council and the Agricultural Improvement Council, after the War, is a vital step towards securing a brighter future for the milk industry.

\section{OPENCAST MINING}

\author{
By PROF. J. A. S. RITSON, O.B.E. \\ Imperial College of Science and Technology
}

$\mathrm{D}$ URING recent months the provision of sufficient coal to meet the growing needs in Great Britain of the munition industry, as well as the domestic consumer, has been exercising the minds of the public and has been the subject of considerable discussion in the Press and both Houses of Parliament. Among the many suggestions for increasing the war-time output, the winning of coal by opencast methods has been mentioned. Opencast workings or opencuts are surface excavations in which the overburden is stripped by hand or mechanical excavators, thereby laying bare the mineral, which is afterwards broken and loaded into wagons or lorries by methods similar to those used for removing the overburden. In some localities in Great Britain the conditions are known to be suitable for the successful application of this method of working and intensive prospecting may result in the discovery of more. Several estimates of the total amount of coal available and also of the amount that can be extracted in the current year have been given wide publicity, but the facts, as so far proved, suggest these figures are optimistic.

The coal seams outcrop at the surface in nearly all the coalfields of Great Britain, but in the majority of cases they have already been worked by the 'old 